\title{
EPIDEMIOLOGY CHARACTERISTICS AND IMMUNIZATION STATUS OF DIPHTHERIA PATIENTS IN EAST JAVA PROVINCE IN 2018
}

\author{
Karakteristik Epidemiologi dan Status Imunisasi Penderita Difteri di Provinsi Jawa Timur Tahun 2018
}

\section{Dwi Rismayanti Wigrhadita}

Public Health Faculty, Universitas Airlangga, dwi.rismayanti.wigrhadita-2015@ fkm.unair.ac.id Corresponding Author: Dwi Rismayanti Wigrhadita, dwi.rismayanti.wigrhadita-2015@fkm.unair.ac.id, Department of Epidemiology, Public Health Faculty, Universitas Airlangga, Dr. Ir. H. Soekarno Street, Mulyorejo, Surabaya, East Java, Indonesia, Postal Code 6115

\section{ARTICLE INFO \\ Article History: \\ Received March, 28 ${ }^{\text {th }}, 2019$ \\ Revised form May, 22 ${ }^{\text {nd }}, 2019$ \\ Accepted June, 26 ${ }^{\text {th }}, 2019$ \\ Published online August, 30 ${ }^{\text {th }}, 2019$}

\author{
Keywords: \\ diphtheria cases; \\ epidemiology characteristics; \\ immunization status; \\ diphtheria sufferers; \\ east java province
}

Kata Kunci:

kasus difteri;

karakteristik epidemiologi;

status imunisasi;

penderita difteri;

provinsi jawa timur

\begin{abstract}
Background: East Java Province is the region with the highest incidence of diphtheria in Indonesia. In the past three years, the number of diphtheria cases amounted to 758 cases and resulted in three mortalities. Objective: This study aims to describe the epidemiological characteristics and diphtheria immunization status of patients in East Java province in 2018. Methods: This study employed descriptive research with cross-sectional design. This study utilized secondary data of publication profiles from the East Java Provincial Health Office in 2018. The population was the entire diphtheria patients in East Java province, 2018. The samples were taken by using the total population sampling technique. The variables in this study were epidemiological characteristic and immunization status of diphtheria patients. The data analysis employed a univariate analysis by providing the frequency table. Results: Based on the records, diphtheria infected the children more often but, in 2018, it was also found in adults. This circumstance is proven by the findings that the patients were aged $\geq 19$ years $(33.11 \%)$ and were males $(50.60 \%)$. In 2018 , diphtheria patients number experienced an increase and decrease fluctuatingly as well as quite prevalence in some areas in the province of East Java. Diphtheria patients were predominanted by incomplete immunization status and unimmunized patients. Conclusion: The completeness status of diphtheria immunization has a very important role in the incidence of diphtheria cases in East Java Province in 2018, particularly the status of patients who is not complete and unimmunized.
\end{abstract}

C2019 Jurnal Berkala Epidemiologi. Published by Universitas Airlangga. This is an open access article under CC-BY-SA license (https://creativecommons.org/licenses/by-sa/4.0/)

\section{ABSTRAK}

Latar Belakang: Provinsi Jawa Timur merupakan wilayah dengan insiden difteri tertinggi di Indonesia. Jumlah kasus difteri di Provinsi Jawa Timur selama 3 tahun terakhir sebanyak 758 kasus dan angka kematian sebanyak 3 orang. Tujuan: Penelitian ini bertujuan untuk menggambarkan karakteristik epidemiologi dan status imunisasi penderita difteri di Provinsi Jawa Timur tahun 2018. Metode: Penelitian ini merupakan jenis penelitian deskriptif dengan rancang 


\begin{abstract}
bangun cross sectional. Penelitian ini menggunakan data sekunder dari publikasi profil Dinas Kesehatan Provinsi Jawa Timur tahun 2018. Populasi yang digunakan adalah keseluruhan penderita difteri di Provinsi Jawa Timur tahun 2018. Sampel diambil dengan menggunakan total population. Variabel dalam penelitian ini yaitu karakteristik epidemiologi dan status imunisasi penderita difteri. Analisis data berupa analisis univariate dengan menyajikan tabel frekuensi. Hasil : Penderita difteri berdasarkan riwayatnya lebih sering menyerang usia anak, namun di tahun 2018 penderita difteri juga ditemukan pada usia dewasa. Hal ini dibuktikan dengan ditemukannya penderita berusia $\geq 19$ tahun $(33,11 \%)$ dan berjenis kelamin laki-laki (50,60\%). Penderita difteri berdasarkan waktu terjadi peningkatan dan penurunan secara fluktuatif di tahun 2018 serta cukup tersebar di beberapa wilayah di Provinsi Jawa Timur. Penderita difteri didominasi dengan status imunisasi yang tidak lengkap dan tidak diberi imunisasi. Kesimpulan : Status kelengkapan imunisasi difteri sangat berperan penting dalam terjadinya kasus difteri di Provinsi Jawa Timur tahun 2018, khususnya status penderita yang tidak lengkap dan tidak pernah melakukan imunisasi seumur hidupnya.
\end{abstract}

(C2019 Jurnal Berkala Epidemiologi. Penerbit Universitas Airlangga. Jurnal ini dapat diakses secara terbuka dan memiliki lisensi CC-BY-SA (https://creativecommons.org/licenses/by-sa/4.0/)

\section{INTRODUCTION}

Diphtheria is one of the causes of infants and toddlers mortality due to the low immunity and can be prevented by immunization (PD3I) (Ministry of Health RI, 2018). Diphtheria is caused by infection from Corynebacterium diphtheriae (Puspitasari, Supatmini, \& Husada, 2017). During 2000-2016, Indonesia was included as one out of ten countries with the highest diphtheria cases in the world. Indonesia occupied the second-highest place with the most diphtheria cases compared to other SEARO member countries (South-East Asia Region) (Arifin \& Prasasti, 2017). The increasing trend of diphtheria cases in Indonesia happens every year. In 2015, there were 415 cases and 24 deaths from diphtheria disease in Indonesia and, in 2016, the CFR (Case Fatality Rate) of diphtheria reached $5.80 \%$. Diphtheria highest incident occurred in the area of East Java province these years. In 2011 and 2012, the entire counties or cities in East Java have experienced an outbreak of diphtheria (Izza \& Soenarnatalina, 2015). Diphtheria outbreaks recurred in 2016 in East Java, with the number of deaths by 6 people (Ministry of Health RI, 2018). In 2017 diphtheria cases in East Java increased to 460 cases with 16 deaths, and continued to increase in 2018, which occurred to be 758 cases with deaths by 3 people (East Java Provincial
Health Office, 2018). The prevention attempts through immunization were considered insuffcient to control diphtheria cases (Clarke, 2017). Outbreak Response Immunization (ORI), Backlog Fighting (BLF), and National Immunization Week (PIN) were a form of programs made in anticipation of the outbreak, however diphtheria cases were constantly increasing. The increasing trend which continued to occur in East Java was the result of diphtheria prevention programs through insuffcient diphtheria immunization scope, especially 7 doses diphtheria immunization (East Java Provincial Health Office, 2018).

The high incidence of diphtheria can be minimized by immunization. Immunization is a health intervention that can suppress the illness and death in infants due to infections. In addition, to give individual immunity, immunization aims to establish the group immunity (herd immunity). The immunity would be achieved if an area has a high immunization coverage. Immunization coverage, in a region targeted by the government, must exceed $80 \%$ of the national, provincial, district, and even each village (East Java Provincial Health Office, 2018). WHO in 1992 targeted booster administration in school-age children should be able to reach $95 \%$ in all regions (Fitriansyah, 2018). Booster immunization or commonly known as a repeated immunization is the immunization given to children who have 
never been given Hepatitis B immunization until 5 years of age, thus it requires 3 times of administration, and given to children in the 1 st grade who had already got basic immunization (Izza, Lestari, \& Tumaji, 2017). This condition supports that in Indonesia, immunization administration is uneven and almost all children are unimmunized. The absence of the officers was the main reasons why the children could not get immunizations. The other reason was due to the lack of knowledge of mothers on immunization matter, trust in the vaccine delivery, the lack of vaccines availability, and the costs affordability (Rahmawati \& Wahyuni, 2014).

Some studies suggest that the risk of diphtheria incidence comes from the incompleteness diphtheria immunization factors. The Individuals will be more risky to be infected by diphtheria if they are unimmunized (DPT / DT) compared with individuals who have been given immunization (Triana, 2016). It is in line with the results of the study in 2016, which suggested diphtheria case in Bangkalan health center that is dominated by immunization administration. Children who had never received a DPT immunization are five times greater risk for experiencing diphtheria than children who had been immunized (Rahmawati \& Wahyuni, 2014).

The prior research by Izza \& Soenarnatalina (2015) also signifies that immunization DPT3 and DT is a related factor to the number of people with diphtheria. This study has the purpose to describe the epidemiological characteristics and diphtheria immunization status of patients in East Java province in 2018.

\section{METHODS}

This research was descriptive study with a cross-sectional design. This study utilized secondary data derived from secondary data of publication profiles from the East Java Provincial Health Office in 2018. This research was conducted in January 2019. The population sample was the total number of people who were diagnosed with diphtheria from 29 districts and 9 cities in East Java province in 2018. Samples were taken by using the total population. Data were analyzed by univariate presented descriptively with a frequency table. The variables analyzed were characteristics of epidemiology and patients' immunization status with diphtheria. Epidemiological characteristics variable refered to the distribution of diphtheria cases based on epidemiological triangles which could be divided into people, places (regions), and time variables. Diphtheria cases which were spread based on people variable consisting of age groups and sexes. The variable of place (region) of diphtheria distribution cases was classified through districts and cities in the East Java region, and the distribution based on time could be classified through the calculation of the month.

Age was the level of time which was calculated in the number of years since the child was born until the time of the data collection was carried out. Gender is a biological characteristic that is seen from the outside appearance. The immunization status of diphtheria sufferers is the immunization status of infants against the provision of diphtheria immunization which lasts as many as 7 doses. Processing and analysis of data using frequency distribution tables.

\section{RESULTS}

\section{Patient Epidemiology Characteristics of Diphtheria in East Java Province 2018}

Based on the results of secondary data from East Java province, the increased cases occurred from 2016 to 2018 consistently (Figure 1). East Java had the highest number of diphtheria cases reached to 209 cases in 2016 and 6 deaths. In 2017, diphtheria cases in East Java increased to 460 cases with 16 deaths, and continued to increase in 2018, which were 758 cases consisting of 33 cases with positive results mitis, 32 cases with positive results gravis, 421 cases with negative results, 269 cases were unidentified (Figure 2).

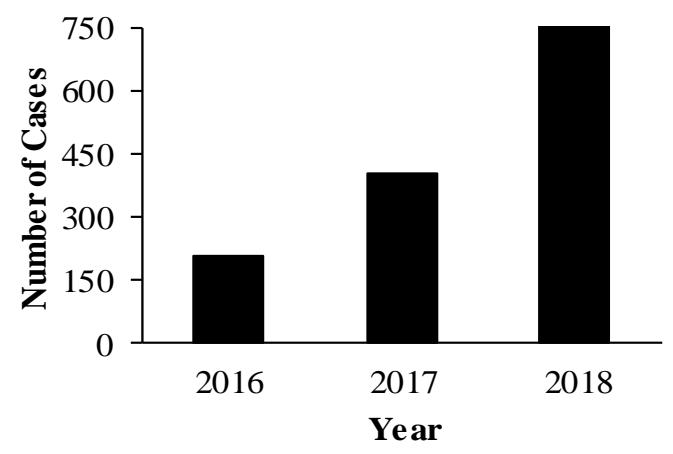

Figure 1. Diphtheria cases in East Java Province during 2016-2018

The results indicated that most patients were $\geq 19$ years of age $(33.10 \%)$ and the least patients' age were $\leq 2$ years $(7 \%)$. Based on the patients' gender, the most dominant diphtheria patients were males $(50.60 \%)$. Based on the distribution area in East Java, the highest diphtheria cases in 
2018, occurred in Surabaya amounted to 75 cases, while the lowest area was in the Bondowoso which occurred by 3 cases. The diphtheria distribution pattern cases were based on the time of months calculation (Figure 4). The results revealed that diphtheria cases occurred in fluctuation during 2018. The highest cases of diphtheria during 2018 occurred in January with 139 cases while the lowest was in June with 27 cases.

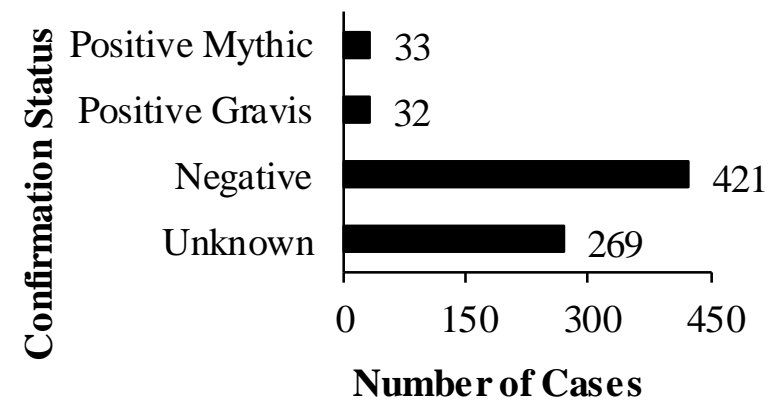

Figure 2. Identification of Diphtheria Cases in East Java Province 2018

\section{Patients Diphtheria Immunization Status In East Java 2018}

The majority of patients' age group with diphtheria was $\geq 19$ years $(33.10 \%)$ and the least age group was $1-2$ years $(6.99 \%)$. The majority of immunized $(70.51 \%)$. In the age group 1-2 years, the majority of diphtheria patients were only administered with diphtheria immunization until the third dose. Incomplete dosing also occured at the age of 3-5 years, 12-18 years, and $\geq 19$ years which was the common age when many immunizations stopped until the third dose only. This circumstance indicated incomplete dosing will affect the occurrence of diphtheria cases. In contrast, the completeness of immunization was dominated by the age of 6-11 years amounted to $2.47 \%$ (Table 2).

\section{Table 1}

Characteristics Variable of Epidemiology Diphtheria Patients In East Java Province 2018

\begin{tabular}{lrr}
\hline Variable & Frequency (n) & $\begin{array}{c}\text { Percentage } \\
(\%)\end{array}$ \\
\hline Age (years) & & \\
$1-2$ & 53 & 7.00 \\
$3-5$ & 134 & 17.70 \\
$6-11$ & 202 & 26.60 \\
$12-18$ & 118 & 15.60 \\
$\geq 19$ & 251 & 33.10 \\
Sex & & \\
$\quad$ Man & 383 & 50.60 \\
$\quad$ Woman & 374 & 49.40 \\
\hline Total & 758 & $100.00 \%$ \\
\hline Sour
\end{tabular}

Source: East Java Provincial Health Office (2018)

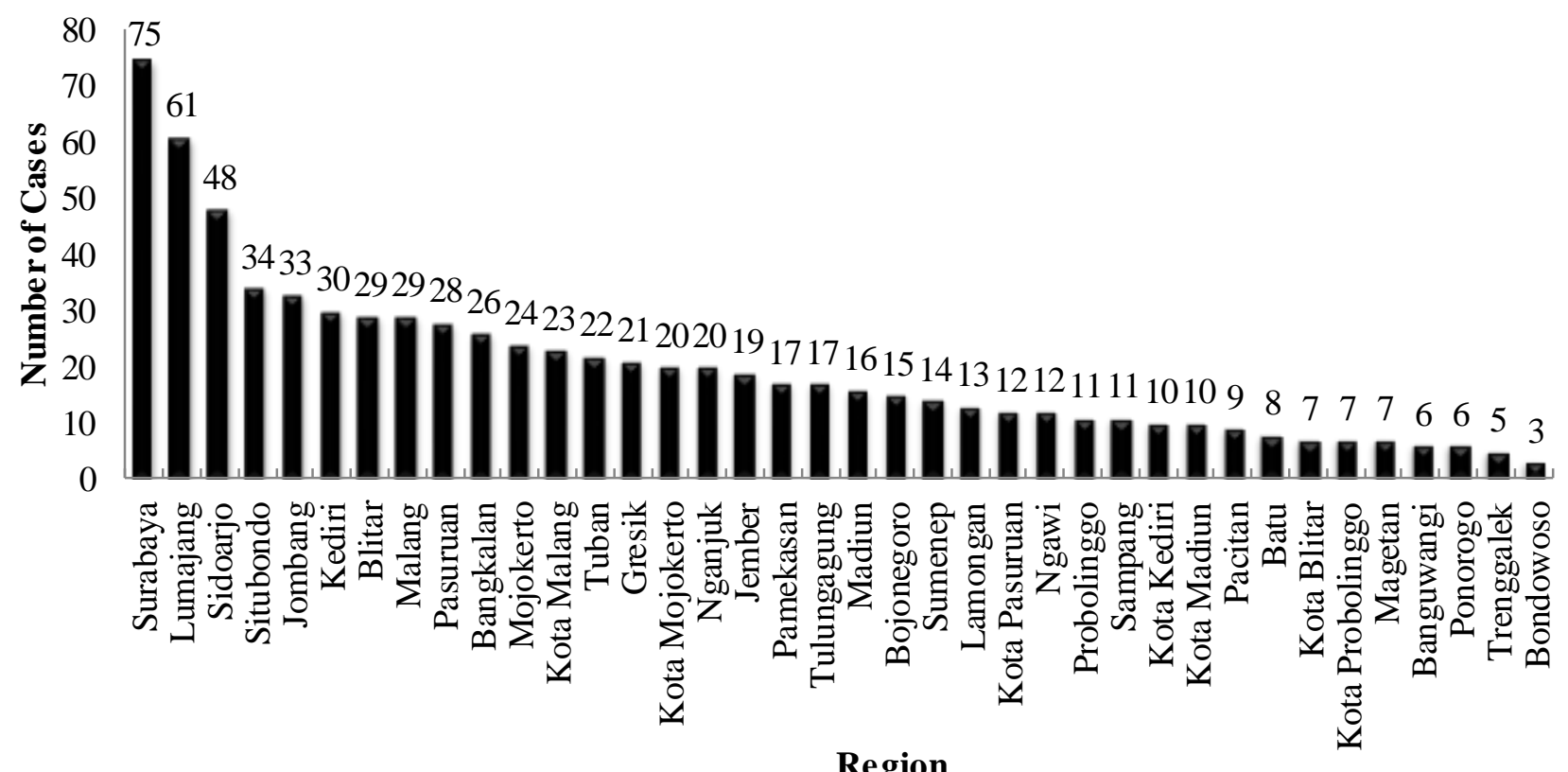

Region

Source: East Java Provincial Health Office (2018)

Figure 3. Diphtheria Case Distribution by Region in East Java Province 2018 


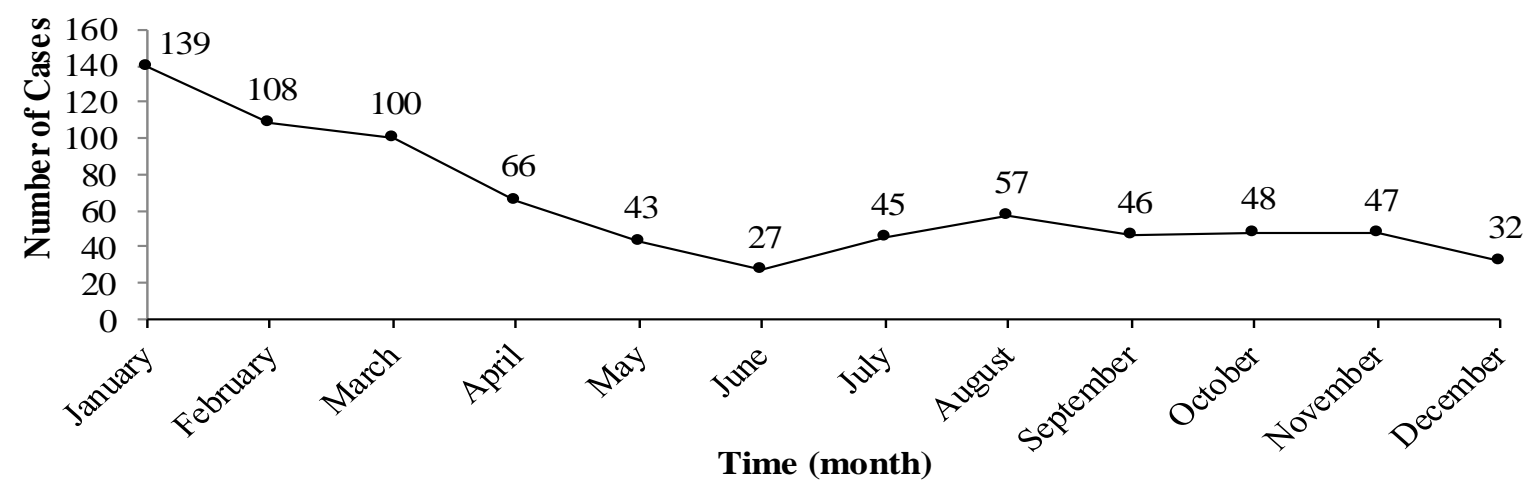

Source: East Java Provincial Health Office (2018)

Figure 4. Distribution of Diphtheria Case based on Time In East Java Province 2018

Table 2

The Patients' Diphtheria Immunization Status Overview in East Java Province 2018

\begin{tabular}{|c|c|c|c|c|c|c|c|c|c|c|c|c|}
\hline \multirow{3}{*}{$\begin{array}{c}\text { Immunization } \\
\text { Status }\end{array}$} & \multicolumn{12}{|c|}{ Patients age Diphtheria } \\
\hline & \multicolumn{2}{|c|}{ 1-2 Years } & \multicolumn{2}{|c|}{ 3-5 Years } & \multicolumn{2}{|c|}{ 6-11 Years } & \multicolumn{2}{|c|}{ 12-18 Years } & \multicolumn{2}{|c|}{$\geq 19$ Years } & \multicolumn{2}{|c|}{ Total } \\
\hline & $\mathbf{n}$ & $\%$ & $\mathbf{n}$ & $\%$ & $\mathbf{n}$ & $\%$ & $\mathbf{n}$ & $\%$ & $\mathbf{n}$ & $\%$ & $\mathbf{n}$ & $\%$ \\
\hline Unimmunized & 15 & 1.98 & 29 & 3.83 & 36 & 4.75 & 42 & 5.54 & 177 & 23.35 & 299 & 39.45 \\
\hline $\begin{array}{l}\text { DPT-HB-Hib } 1 \\
(\text { dose } 1)\end{array}$ & 1 & 0.13 & 1 & 0.13 & 12 & 1.58 & 16 & 2,11 & 10 & 1.32 & 40 & 5.28 \\
\hline $\begin{array}{l}\text { DPT-HB-Hib } 2 \\
\text { (dose } 2)\end{array}$ & 1 & 0.13 & 3 & 0.40 & 3 & 0.40 & 4 & 0.53 & 2 & 0.26 & 13 & 1.72 \\
\hline $\begin{array}{l}\text { DPT-HB-Hib } 3 \text { (3 } \\
\text { doses) }\end{array}$ & 21 & 2.77 & 41 & 5.41 & 50 & 6.60 & 25 & 3.30 & 42 & 5.54 & 179 & 23.61 \\
\hline $\begin{array}{l}\text { DPT-HB-Hib } \\
\text { booster (4 doses) }\end{array}$ & 8 & 1.06 & 38 & 5.01 & 52 & 6.86 & 18 & 2.37 & 13 & 1.72 & 129 & 17.02 \\
\hline $\begin{array}{l}\mathrm{DT}(1 \mathrm{SD})(5 \\
\text { doses) }\end{array}$ & 6 & 0.79 & 15 & 1.98 & 26 & 3.43 & 6 & 0.79 & 1 & 0.13 & 54 & 7.12 \\
\hline $\begin{array}{l}\mathrm{Td}(2 \mathrm{SD})(6 \\
\text { doses) }\end{array}$ & 1 & 0.13 & 6 & 0.79 & 18 & 2.37 & 3 & 0.40 & 2 & 0.26 & 30 & 3.96 \\
\hline $\begin{array}{l}\text { Td }(5 \text { th })(7 \\
\text { doses })\end{array}$ & 0 & 0.00 & 1 & 0.13 & 5 & 0.66 & 4 & 0.53 & 4 & 0.53 & 14 & 1.85 \\
\hline Total & 53 & 6.99 & 134 & 17.68 & 202 & 26.65 & 118 & 15.57 & 251 & 33.11 & 758 & 100.00 \\
\hline
\end{tabular}

Table 3

The Patients' Diphtheria Immunization Status Completeness Overview in East Java Province 2018

\begin{tabular}{lrrrrrrr}
\hline & \multicolumn{3}{c}{ Immunization Status } & \multicolumn{3}{c}{ Total } \\
\cline { 2 - 7 } & \multicolumn{2}{c}{ Age group (years) } & $\mathrm{n}$ & \multicolumn{1}{c}{$\%$} & $\mathrm{n}$ & $\%$ & \multicolumn{2}{c}{ Incomplete } & \multicolumn{1}{c}{$\%$} \\
\cline { 2 - 7 } & 0 & 0.00 & 53 & 6.99 & 53 & 6.99 \\
$1-2$ & 1 & 0.13 & 133 & 17.55 & 134 & 17.68 \\
$3-5$ & 5 & 0.66 & 197 & 25.99 & 202 & 26.65 \\
$6-11$ & 4 & 0.53 & 114 & 15.04 & 118 & 15.57 \\
$12-18$ & 4 & 0.53 & 247 & 32.59 & 251 & 33.11 \\
$\geq 19$ & 14 & 1.85 & 744 & 98.15 & 758 & 100.00 \\
\hline Total & & & & & & &
\end{tabular}

Source: East Java Provincial Health Office (2018) 


\section{DISCUSSION}

\section{The Epidemiology Characteristics of Diphtheria Patients In East Java Province}

The diphtheria has a potential to become the outbreaks. The occurrence of a single case of diphtheria could be stated as the outbreaks (Alfiansyah, 2015). The results of this study revealed that the incidence of diphtheria continued to increase. Increasing cases of diphtheria that occured from 2016 to 2018 due to nonoptimal and imprevalence of immunization administration. These results were also supported by individuals who are still found to have incomplete immunization status and individuals who had never immunized. The efforts by the government through several programs decreased morbidity and mortality number of diphtheria. The government programs are by holding Outbreak Response Immunization (ORI), Fighting Backlog (BLF), and National Immunization Week (PIN) in several counties and cities in East Java (East Java Provincial Health Office, 2018). People with diphtheria cases were dominated by citizens aged $\geq 19$ years $(33.10 \%)$ and male $(50.60 \%)$. The majority of those patients should have been received the complete diphtheria immunization (7 doses). However, at that age, the patients predominantly did not receive immunization (70.51\%) or booster immunization (7.96\%). This circumstance is in line with the research by Fitria, Putra, Yani, \& Basir (2016) that shows as a child grows older, the body titer declines. Research conducted by Fitriansyah (2018) also stated that as a child grows older, the risk of diphtheria infected is increasing, in case the repeated immunization with diphtheria (booster) is not administered . As getting older, a person will interact more with many people. It leds to the opportunity for exposure to the Corynebacterium diphtheriae from outside are larger and makes diphtheria disease will be greater as well.

Diphtheria patients in East Java province in 2018 were predominantly male. The male patient were considered to have activities outside the home more frequent than the female (Fitriansyah, 2018). The number of activities outside the home makes someone would make contact with diphtheria carriers, especially if these activities were mostly carried out in endemic areas or prone to diphtheria. These results differ from study Swart et al (2016), which states that women are more frequently infectedof by the diphtheria than men. The number of Geometric Mean IgG Concentrations (GMC) or diphtheria antibody titers in women is lesser than men. That statement indicates that women are more vulnerable to diphtheria. The results Incidence of diphtheria in East Java depicted the differences with the research that conducted by Sari (2018) The research revealed that gender does not have a correlation with the diphtheria incidences in Surabaya. It is because the differences in immunity as well as gender are not correllated with diphtheria.

The highest case of diphtheria in the East Java Province is in Surabaya. Diphtheria can be caused by the number of 7 doses diphtheria immunization coverage is low. The low coverage of diphtheria immunization will potentially cause diphtheria disease transmission uninterrupted. Diphtheria can easily spread through saliva or food. Someone whose incomplete immunization status will be more risky to get the transmission of diphtheria than someone whose complete immunization status (Hidayati, 2017). The low coverage of immunization in a particular region, which causes an increase in diphtheria cases, requires an epidemiology surveillance system that aims to monitor and evaluate the success of immunization attainment. The final result of this surveillance can be used as a basis to make a decision in preventing and mitigating diphtheria cases. People whose high mobility from one area to another also risky to increase the opportunity to be a germ carrier (Rahman, Hargono, \& Susilastuti, 2016).

The diphtheria cases that occured at 2018 were fluctuating. The highest diphtheria case number was in January while the lowest was in June. The high number of diphtheria cases in early 2018 was due to the impact of the high number of diphtheria cases in the previous year. In 2017, there were 460 cases with 16 deaths. The high number of diphtheria cases along with the absence of the Outbreak Response Immunization (ORI) program made January as the peak month for diphtheria cases in 2018. The ORI program conducted in three rounds in the year of 2018, which are in January, July, and November. The decline of diphtheria cases occured in June. The decline was believed as a result of repeated immunization (booster) had been administered, as a form of defense efforts against plague outbreaks during the year. The low number of diphtheria cases also supporting that the ORI program was a success and became one of the attempts to prevent the infection of diphtheria (East Java Provincial Health Office, 2018). 


\section{The Status of Diphtheria Immunization Patients in East Java Province}

According to Ministry of Health RI (2018) immunization is a way to prevent infectious illnesses as well as to suppress and reduce mortality in children. Diphtheria is a contagious disease and immunization serve as an important effort to prevent and control the disease. Immunization should be as active way to induce and enhance the immune system of individuals to diseases, especially infectious diseases. DPT immunization when the age of the baby and DT immunization at school-age children is an attempt to minimize the occurrence of diphtheria (East Java Provincial Health Office, 2018). The age group $\geq 19$ years old should have gained a complete immunization which is seven doses, but the majority of patients with diphtheria dominated by age group $\geq 19$ years old were unimmunized or had incomplete immunization status. Booster immunization program commenced in 2016, therefore many people did not know the importance of immunization. It is congruent with the research by Arifin \& Prasasti (2017) that stated the provision of three doses of DPT with one repeated dose may affect the effectiveness of vaccination. Giving a complete DPT will be more effective in protecting a person from diphtheria.

Incomplete immunization course will also affect the dose of vaccine which is not sufficient to produce an antibody, therefore it does not provide optimum immunity in the body and causes a person to be prone to be infected by diphtheria (IDAI, 2011). The immune system will be high if the vaccine doses given are 2 to 3 times more than the vaccination with one time frequency (Radian, Suryawati, \& Jati, 2018).

Based on the diphtheria immunization status, individuals who had never got immunization, were once infected by diphtheria. The high number of patients who unimmunized indicated that a person could be infected easier with diphtheria. The majority of the age group with incomplete immunization status was the age group $\geq 19$ years. The low immunity is align to the age. It is in line with the research by Arifin \& Prasasti (2017) which sated that the absence of diphtheria immunization will put the children at risk of getting diphtheria more easily. In addition, the children unimmunized will have lower immunity than the children who have been diphtheria immunized. Children who are not completely immunized are five times more likely to be infected by diphtheria than someone with complete immunization status. Another study by Saifudin,
Wahyuni, \& Martini (2016) conducted in Blitar suggested the incidence of diphtheria were closely related to immunization status. The immunization administration of DPT-HB-Hib aims to give the the immune system strength during 1-3 years (94\% $-100 \%$ ). The fourth dose administration as a booster immunization is also useful to add immunity in ages 5 to 7 years, while administering $\mathrm{Td}$ booster aged 10-18 years as a protective antibody titer will increase to protect against the diphtheria and tetanus (Fitriansyah, 2018). The immunity against diphtheria disease occurs due to a person rapid ability in making anti-toxin and its presence in the body. The ability comes from active immunization or vaccination. The immunity in the body will keep a person from getting sick easily. It is due to the immune system will protect a person from infectious diseases. Children with incomplete immunization status will be highly susceptible to infection and experience of disability or death (Kaunang, Rompas, \& Bataha, 2016).

Incomplete immunization can be caused by many factors, such as the affordability to the place of health care, the timing of immunization, vaccine availability, family problems, long time to wait, as well as immunizations costs (Triana, 2016). It was explained in a research by Izza, Lestari, \& Tumaji (2017) which stated that several mothers did not administer the complete immunization because of the lack of information from the midwife. Incomplete immunization can also occur due to the assumption of DPT-HB-Hib given during infancy is sufficient thus it does not need to have diphtheria immunization booster. This statement is supported by another research conducted by Scobie et al (2015), which indicated the mother's ignorance was the reason of incomplete immunization status. The improving understanding and awareness is considered to be the right solution and can be delivered by health workers through socialization conducted in integrated health post (posyandu) and other community activities.

\section{Research Limitation}

The research limitation is in the lack of information that explains the reasons of incomplete immunization administration. The information obtained is only a number of cases in the form of numbers, time information in the form of the month and year, as well as the places in the form of the names of the cities and counties. Hence, it is not sufficiently profound to find out 
the reasons why the immunization is not administered completely.

\section{CONCLUSION}

The distribution of diphtheria cases has increased, starting from 2016 to 2018 in East Java Province. The epidemiological characteristic variable of diphtheria patients, based on person variable, indicates that the majority of patients are aged $\geq 19$ years and are males. Based on place variable, the highest diphtheria events occur in Surabaya and predominantly occurred in January while the least occurred in June.

The completeness of 7 doses of diphtheria immunization is very important to suppress diphtheria in East Java Province in 2018. It is corroborated from the results of this research that indicates that the majority of diphtheria patients in East Java Province have incomplete immunization status or have never had immunizations in their lifetime.

\section{ACKNOWLEDGEMENT}

The writer would like to extend her gratitude to the head of the Surveillance and Immunization Section of the Provincial Health Office and its staff who were willing to give an opportunity, assistance, and guidance in analyzing and discussing the cases of diphtheria in East Java province which obtained by the Surveillance Team East Java Provincial Health Office.

\section{REFERENCES}

Alfiansyah, G. (2015). The epidemiological investigation of diphtheria outbreaks in Blitar District in 2015. Jurnal Universitas Negeri Malang, 2(1), 1-6.

Arifin, I. F., \& Prasasti, C. I. (2017). Factors that associated with cases of diphtheria in children at Bangkalan Health Center in 2016. Jurnal Berkala Epidemiologi, 5(1), 26-36. https://doi.org/10.20473/jbe.v5i1.2017.26-36

Clarke, K. E. N. (2017). Review of the epidemiology of diphtheria 2000-2016. https://doi.org/10.1371/journal.pone.0044878

East Java Provincial Health Office. (2018). Reports of diphtheria surveillance in Surabaya City in 2015-2017. East Java Provincial Health Office. Kota Surabaya.

Fitria, L., Putra, A. E., Yani, F. F., \& Basir, D. (2016). Levels of interferon gamma lymphocyte cell culture in children who received BCG vaccination. Sari Pediatri,
$18(1)$,

21-26.

https://doi.org/10.14238/sp18.1.2016.21-26

Fitriansyah, A. (2018). An overview of the history of diphtheria immunization in patients with diphtheria in the city of Surabaya in 2017. Jurnal Berkala Epidemiologi, 6(2), 103-111. https://doi.org/10.20473/jbe.v6i22018.103111

Hidayati, R. (2017). Factors that influence the incidence of diphtheria in the city of Padang. UNES Journal of Social And Economics Research, 2(2), 180-187. https://doi.org/10.31933/ujser.2.2.180187.2017

IDAI. (2011). National immunization guidelines in Indonesia (4th ed.). Jakarta: Indonesian Pediatrician Association.

Izza, N., Lestari, D., \& Tumaji. (2017). Parental factors and immunization status of DPT children 12-36 months in Ketapang District and Sokobanah District, Sampang Regency. Buletin Penelitian Sistem Kesehatan, 20(2), 43-51.

Izza, N., \& Soenarnatalina. (2015). Analysis of spatial data on diphtheria in East Java Province in 2010 and 2011. Buletin Penelitian Sistem Kesehatan, 18(2), 211219.

Kaunang, M. C., Rompas, S., \& Bataha, Y. (2016). Relationship between basic immunization and Kembes community health centers, District of Tombulu, Minahasa Regency. $e$ journal Keperawatan (e-Kp), 4(1), 1-8.

Ministry of Health RI. (2018). Indonesian Health Profile at 2017. Ministry of Health RI. Jakarta.

Puspitasari, D., Supatmini, E., \& Husada, D. (2017). Clinical description of children with diphtheria in Dr. Soetomo General Hospital. Jurnal Ners, 7(2), 136-141.

Radian, S. A., Suryawati, C., \& Jati, S. P. (2018). Evaluation of the implementation of diphtheria outbreak response immunization (ORI) activities in Semarang City Mijen Health Center in 2018. Jurnal Kesehatan Masyarakat (e-Journal), 6(5), 179-188.

Rahman, F. S., Hargono, A., \& Susilastuti, F. (2016). Epidemiological investigation of diphtheria outbreaks in Geneng and Karang Jati Subdistricts, Ngawi District in 2015. Jurnal Wiyata, 3(2), 199-213.

Rahmawati, A. I., \& Wahyuni, C. U. (2014). Factors that influence the completeness of basic immunization in the village of North Krembangan. Jurnal Berkala Epidemiologi, 
2(1), 59-70.

Saifudin, N., Wahyuni, C., \& Martini, S. (2016). Risk factors for diphtheria in Bliter District in 2015. Jurnal Wiyata Indonesia, 3(1), 6166.

Sari, D. D. (2018). Factors in mothers related to the provision of basic infant immunization in the working area of the Korpri Health Center, Sukarame District, Bandarlampung. Undergraduated Thesis. Faculty of Medicine. Universitas Lampung.

Scobie, H. M., Ray, A., Routray, S., Bose, A., Bahl, S., Sosler, S., ... Anand, A. (2015). Cluster survey evaluation of a measles vaccination campaign in Jharkhand, India, 2012. PLoS ONE, 10(5), 1-15. https://doi.org/10.1371/journal.pone.0127105

Swart, E. M., van Gageldonk, P. G. M., de Melker, H. E., van der Klis, F. R., Berbers, G. A. M., \& Mollema, L. (2016). Long-term protection against diphtheria in the Netherlands after 50 years of vaccination: results from a seroepidemiological study. PloS one, 11(2), $1-15$.

https://doi.org/10.1371/journal.pone.0148605

Triana, V. (2016). Factors related to the provision of complete basic immunization in infants in 2015. Jurnal Kesehatan Masyarakat Andalas, $\quad 10(2), \quad 123-135$. https://doi.org/10.24893/jkma.10.2.123135.2016 